DULEBA Szabolcs

\title{
AZ INTERPRETIVE STRUCTURAL MODELLING (ISM) MÓDSZERÉNEK ÉS EGY LEHETSÉGES ALKALMAZÁSÁNAK BEMUTATÁSA
}

A vezetôi döntések támogatását több matematikai (többek között operációkutatási) alapon nyugvó módszer segítheti. Az Interpretive Structural Modelling (ISM) egy, a nemzetközi menedzsmenttudományokban széles körben, elsôsorban stratégiai döntéshozatalra alkalmazott operációkutatási metódus. Komplex, többkritériumos döntési problémáknál szisztematikus segítséget nyújt az egyes tényezók kapcsolódásainak és kölcsönhatásainak feltárására. Számos sikeres - mind a tudományos, mind az üzleti életben történt alkalmazása ellenére hazánkban kevéssé ismert. A jelen tanulmány célja, hogy részletesen bemutassa az ISM-et, továbbá egy modell eredményeit, és azok értelmezését is közölje. ${ }^{1}$

\section{Kulcsszavak: ISM, döntéstámogatás, többkritériumos problémák}

Az ISM-et bonyolult döntési problémák tényezói közötti összefüggések megállapításának céljából alkották meg. Elsố tudományos leírása óta (Malone, 1975; Warfield, 1976) különböző menedzsmentterületeken alkalmazták. A bemutatás óta eltelt közel 40 év semmit sem csorbított a módszer aktualitásán, napjainkban is népszerú tudományos és üzleti körökben egyaránt. Pfohl et al. (2011) tanulmányában kiemelte, hogy az ISM-eljárás a rendszerelemek kapcsolódásainak vizsgálatakor megbízhatóbbnak bizonyult az összes többi tesztelt módszernél. Tabrizi et al. (2010) a tudásmenedzsment kritériumainak kapcsolódási gráfját alkotta meg a segítségével, míg Eswarlal et al. (2011) ezzel a módszerrel a fenntartható fejlődés szempontjából vizsgálta a megújuló energiahordozók alkalmazhatóságát. Pramod és Branwet (2010) egy telekommunikációs ellátási lánc szereplőinek viselkedését elemezte kutatásában az ISM-mel, Mandal és Deshmukh (1994) pedig beszállítók kiválasztásának komplex végrehajtására használta. Megrendelő-beszállító kapcsolatok értékelő feltárása a metódussal Thakkar et al. (2008) tudományos cikkében olvasható. Több esetben használták ellátási láncok kockázatcsökkentésének vizsgálatára az egyes elemek kölcsönhatásainak szisztematikus modellezési képessége miatt (Faisal et al.,
2006). Számos példát találunk vállalatok vagy ellátási láncok produktivitásának növelésére is az ISM-modellezéssel, Ravi et al. (2005) számítógép-alkatrészek ellátási láncára, Qureshi et al. (2007) pedig kiszervezett logisztikai tevékenységek esetén a beszállítók produktivitásának segítésére alkalmazta a módszert.

A tudományos irodalomban fellelhetô néhány tanulmány, melyben az ISM-et más módszerekkel kombinálva is alkalmazzák, valamint egy összetett kutatás egyik fázisában kap szerepet. Néhány szerzô (pl. Gorvett - Liu, 2007) az Analytic Hierarchy Processszel, azaz az AHP-vel együtt használta, a döntési folyamatban az ISM a döntési kritériumok hierarchikus kapcsolódásainak megállapítására szolgált, így az elemeket AHP-modellben lehetett értékelni a döntéshozóknak. Az AHP-eljárásokban ugyanis előfeltétel a döntési elemek hierarchikus rendje, amelyet így szisztematikus módszerrel lehetett megkapni a korábbi, kevésbé megbízható módokkal szemben. Azokban az esetekben, amikor nem állítható fel tiszta hierarchia a döntési elemek között, vagyis a kapcsolódások sokrétúbbek, az ISM-et az Analytic Network Process-szel, azaz az ANP-vel kombinálhatjuk sikeresen, erre példa Huang et al. (2005) kutatása. 
A következő fejezetben az ISM elméleti hátterének rövid bemutatása következik, mely elsôsorban a Boolealgebra sajátosságait emeli ki a módszer vonatkozásában. A tanulmány alkalmazási megközelítésú jellegéból adódóan a részletesebb matematikai bemutatástól eltekintünk.

Ezt követően egy konkrét, közlekedési problémára vonatkozó alkalmazását mutatjuk be a metódusnak, lépésenként leírva az applikációt, és ábrákkal, táblázatokkal segítve a szöveg megértését.

\section{A módszer bemutatása}

Tanulmányunkban az ISM-et Warfield (1976), valamint Huang et al. (2005) alapján mutatjuk be. Ahogy a Bevezetésben utaltunk is rá, az ISM képes meghatározni egy döntési probléma összes elemének kapcsolódásait és egymásra hatását. Ezáltal meghatározható minden egyes elem befolyásoló ereje (driving power) és befolyásoltsága (dependency) a döntési struktúrán belül. Hangsúlyozni kell azonban, hogy a módszer nem képes kezelni a kapcsolódások erôsségét, mindössze a kapcsolatok meglétéról és irányáról - vagyis, hogy melyik a befolyásoló és melyik a befolyásolt elem a kapcsolatban - szolgáltat információkat.

Az alkalmazás elsô lépéseként azonosítani kell a döntésben szereplő elemeket. Ilyenek lehetnek például egy vállalat beszállítói értékelésének szempontjai, egy beruházás megtérülési mutatói stb.

Ezt követően az úgynevezett „,relációs mátrix” megalkotása következik. Ez egy bináris (csak 0 és 1 elemeket tartalmazó) és kvadratikus (a sorok és oszlopok száma megegyezik) mátrix, melyet a következó elv alapján konstruálunk:

$a_{i j}=1$, ha az , $i$ ” elem hatással van a ,,j” elemre,

$a_{i j}=0$, egyéb esetben.

A relációs mátrix (D) általános struktúrája az 1 . táblázatban látható.

A relációs mátrix általános alakja

\begin{tabular}{|c|c|c|c|c|}
\hline & $\mathrm{e}^{1}$ & $\mathrm{e}^{2}$ & $\ldots$ & $\mathrm{e}^{\mathrm{n}}$ \\
\hline $\mathrm{e}^{1}$ & 0 & $\mathrm{a}^{12}$ & $\ldots$ & $\mathrm{a}^{1 \mathrm{n}}$ \\
\hline $\mathrm{e}^{2}$ & $\mathrm{a}^{21}$ & 0 & $\ldots$ & $\mathrm{a}^{2 \mathrm{n}}$ \\
\hline$\ldots$ & $\ldots$ & $\ldots$ & 0 & $\ldots$ \\
\hline $\mathrm{e}^{\mathrm{n}}$ & $\mathrm{an}^{1}$ & $\mathrm{an}^{2}$ & $\ldots$ & 0 \\
\hline
\end{tabular}

Forrás: saját szerkesztés

Itt az

$e_{i}$ az i-dik elem a döntési rendszerben,

$a_{i j}$ jelöli a kapcsolatot az i-dik és a j-dik elem között.
(D) elemeit a döntéshozók töltik ki szakmai tudásuk és a problémáról meglévő elképzelésük alapján. Ajánlatos egy workshop keretein belül az értékeléseket megtenni, lényeges, hogy a végeredmény tükrözze a döntéshozói menedzsercsoport közös véleményét az elemek kapcsolódásáról. Az eljárás többi lépése nem igényel újabb döntéshozói szerepet, a menedzserektől független kalkulációkból áll. Ezután a következő két lépés kell megtennünk:

$$
R M=D+I
$$

Tehát a relációs mátrixhoz hozzáadjuk az egységmátrixot (I), ezáltal a fóátló csupa 1-es számból fog állni, ezt az új mátrixot nevezzük elérhetőségi mátrixnak ( $\mathrm{RM}$, reachability matrix).

$$
R M^{k}=R M^{k+1} \quad k>1,
$$

ahol a k hatványkitevơket jelöl, $\mathrm{RM}^{*}$ pedig az úgynevezett végső elérhetőségi mátrixot.

A (2)-es lépés egy nagyon lényeges mozzanat az eljárásban, és a módszer egyik legtöbb pluszinformációval szolgáló fázisa. A bináris mátrix megfelelő hatványokra emelésével ugyanis az elemek tranzitivitását érhetjük el, azaz érvényesülhet az a logikai feltétel, hogy amennyiben egy elem hatással van egy másikra, amely hatást gyakorol egy harmadikra, úgy figyelembe kell venni az elsô hatását is a harmadikra. Azaz:

$$
\begin{array}{ll}
\text { ha } & a_{i j}=1, \\
\text { és } & a_{j k}=1, \\
\text { akkor } & a_{i k}=1 .
\end{array}
$$

Az elérhetôségi mátrix hatványokra emelése tehát biztosíthatja azt a tranzitivitást, amely sem az eredeti relációs mátrixnak, sem az elérhetôségi mátrixnak nem feltétlenül sajátja. (Amennyiben a vizsgált döntési probléma sok elemból áll, szinte biztosan nem lesz tranzitív sem (D), sem (RM), hiszen az emberi mentális képességek nem követhetik a több tagból álló tranzitivitási láncokat.)

Felhívjuk arra a figyelmet, hogy a végsô elérhetôségi mátrixot a Boole-algebra múveletei segítségével célszerú megalkotni a binaritás megôrzésének céljából. Ez a következő múveleti operátorok teljesítését feltételezi: $1+1=1$ és $1 \times 1=1$. (2) során tehát plusz 1 -eseket adunk az eredeti elérhetôségi mátrixhoz, hogy a tranzitív kapcsolódások is kifejeződjenek a végsô elérhetôségi mátrixban. A pluszinformációt az jelenti, hogy a több tagból álló tranzitív kapcsolódások feltárulnak a hatványra emelés során, így az elemek kapcsolódásának teljes struktúrája feltárul a döntéshozók előtt. Ahogy (2) is mutatja, a hatványozást addig kell folytatni, amíg a bináris mátrix stabillá nem válik, vagyis a további 
hatványra emelések már nem változtatnak a mátrix elemein. Minél hosszabb kapcsolódási láncok találhatók a döntési problémában, annál magasabb hatványra kell emelni az eredeti mátrixot, a hatványkitevớk nagysága ugyanis megegyezik a láncok elemszámával.

A következô lépésben kiszámoljuk az egyes elemek elérhetôségi halmazát (R[ti]) és befolyásolt halmazát $(\mathrm{A}[\mathrm{ti}]) .(\mathrm{R}[\mathrm{t} \mathrm{i}])$ azt mutatja meg, hogy az i-dik elem mely más elemekre gyakorol hatást a döntési struktúrán belül. (A[ti]) azt mutatja meg, hogy az i-dik elemre mely más elemek hatnak a döntési struktúrán belül. A kalkuláció a következóképpen végezhetố el:

$$
\begin{aligned}
& \mathrm{R}(\mathrm{ti})=\left\{e_{i} \mid m_{j i_{*}}{ }^{*}=1\right\} \\
& \mathrm{A}(\mathrm{ti})=\left\{e_{i} \mid m_{i j}{ }^{*}=1\right\}
\end{aligned}
$$

ahol $m_{i j}{ }^{*}$ jelöli az i-dik sor és a j-dik oszlop értékeit, $m_{j i}{ }^{*}$ pedig a j-dik sor és az i-dik oszlop értékeit.

Ezután a döntési elemeket hierarchikus szintekbe sorolhatjuk befolyásoló erejük és rendszeren belüli függóségük alapján, illetve az elemek kapcsolódási gráfját is megrajzolhatjuk. A szintek meghatározásához a következó kalkulációs szabályt kell követni:

$$
\mathrm{R}(\mathrm{ti}) \cap \mathrm{A}(\mathrm{ti})=\mathrm{R}(\mathrm{ti}),
$$

tehát az elsố szint elemeit úgy választhatjuk ki, hogy megkeressük azokat a döntési tényezóket, amelyeknek megegyezik az elérhetôségi és befolyásolt halmazának metszete: $\mathrm{R}(\mathrm{ti}) \cap \mathrm{A}(\mathrm{t} \mathrm{i})$, az elérhetôségi elemhalmazával: $\mathrm{R}(\mathrm{ti})$. Ha kiválasztottuk az elsố hierarchikus szint elemeit, azokat töröljük a kalkulációból, így a következő szintre is alkalmazhatjuk az (5)-ös számítási szabályt. Addig folytatjuk tovább a fent leírt számításokat, amíg a döntési probléma minden elemét be nem soroljuk valamely klaszterbe a befolyásoló erő és függőség alapján.

\section{Egy lehetséges alkalmazás: közforgalmú közleke- désirendszer-elemek kapcsolódásainak feltárása}

Amennyiben egy közforgalmú közlekedési rendszer elemeinek fejlesztési szükségességét vizsgáljuk döntésünkben, igen összetett problémával szembesülünk. Először is, nehéz egy modellben az összes rendszerelemet szerepeltetni. Másodszor, a rendszerben találhatók kvantitatív, azaz számszerúen kifejezhető összetevôk (pl. járatsúrúség stb.), de ugyanúgy tartalmaznia kell a modellnek kvalitatív (pl. a menetrendek érthetősége stb.) összetevőket is, ezek együttes kezelése pedig metodológiai nehézséget okoz. Harmadszor ezek a tényezók nem függetlenek egymástól, az egyik fejlesztése pozitív hatást gyakorolhat más rendszerösszetevőkre, vagy épp ellenkezőleg, akár negatívan is érintheti azokat.
Megelőző kutatásunkban az alapfeladat az volt, hogy próbáljuk meg egy városi buszközlekedési rendszer elemeire vonatkozó utaspreferenciákat megtalálni, azaz elemezzük, a felhasználók a rendszernek mely részeit tartják leginkább fejlesztendőnek. A kutatás eredményeit részletesen Duleba et al. (2012) tanulmánya mutatja be.

Az eredményekre vonatkozóan viszont úgy találtuk, hogy azok csak egymástól független tényezók esetén érvényesek, így a modellben a rendszeren belül integrálni kell a kapcsolatokat és a kölcsönhatásokat. Ennek megvalósítására alkalmas, ha lefolytatjuk az ISMeljárást a modellre. 24 elemet különböztettünk meg a közlekedési rendszer leírására, ezeket tartalmazza a 2. táblázat.

2. táblázat

\section{A közlekedési rendszer elemei és jelölésük a modellben}

\begin{tabular}{|l|l|}
\hline Szolgáltatási minőség & $\mathrm{r} 1$ \\
\hline Utazási minóség & $\mathrm{r} 2$ \\
\hline Nyomonkövethetőség & $\mathrm{r} 3$ \\
\hline Térbeli elérhetóség & $\mathrm{r} 4$ \\
\hline Közvetlenség & $\mathrm{r} 5$ \\
\hline Idóbeli elérhetóség & $\mathrm{r} 6$ \\
\hline Sebesség & $\mathrm{r} 7$ \\
\hline Megbízhatóság & $\mathrm{r} 8$ \\
\hline Fizikai kényelem & $\mathrm{r} 9$ \\
\hline Mentális kényelem & $\mathrm{r} 10$ \\
\hline Utazási biztonság & $\mathrm{r} 11$ \\
\hline Menetrend-érthetőség & $\mathrm{r} 12$ \\
\hline Utazás elótti infók & $\mathrm{r} 13$ \\
\hline Utazás közbeni infók & $\mathrm{r} 14$ \\
\hline Megállók elérése & $\mathrm{r} 15$ \\
\hline Megállók biztonsága & $\mathrm{r} 16$ \\
\hline Megállók kényelme & $\mathrm{r} 17$ \\
\hline Átszállások & $\mathrm{r} 18$ \\
\hline Kapcsolódás & $\mathrm{r} 19$ \\
\hline Járatsúrúség & $\mathrm{r} 20$ \\
\hline Idóbeli korlátozások & $\mathrm{r} 21$ \\
\hline Utazási idő & $\mathrm{r} 22$ \\
\hline Várakozási idő & $\mathrm{r} 24$ \\
\hline Megállóelérési idő & \\
\hline
\end{tabular}

Forrás: saját szerkesztés

Ahogy látható, általános tényezók (pl. utazási minôség) ugyanúgy szerepelnek a táblázatban, mint specifikusak (pl. megállóelérési idő). Az ISM egyik előnye, 


\section{A közlekedési rendszer elemeinek elérhetôségi mátrixa}

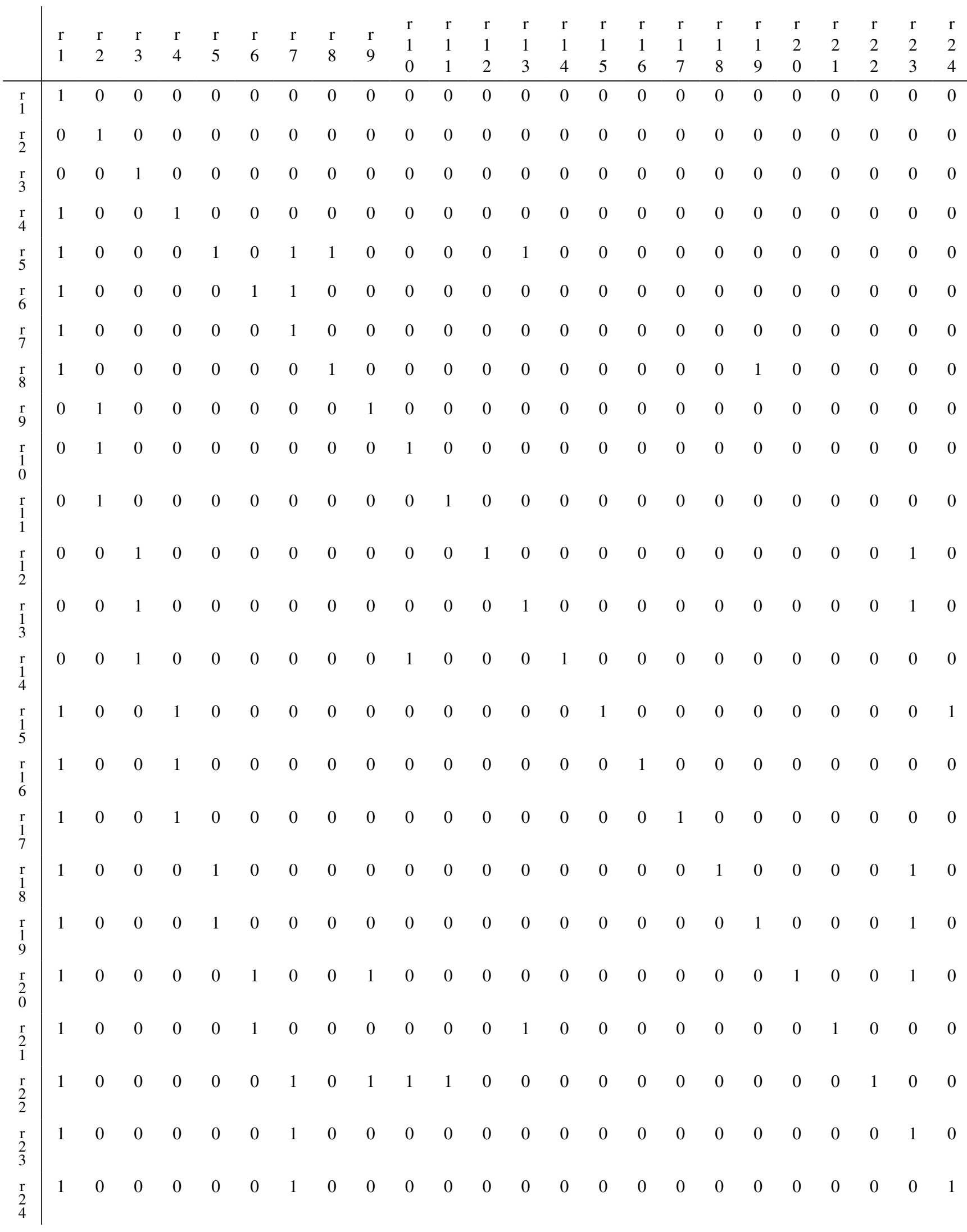

Forrás: saját szerkesztés 
hogy általános és specifikus faktorokat képes együttesen kezelni, természetesen a kapcsolódásokban és a felépített hierarchiában ezek általában kifejezésre jutnak (az általánosabb faktoroknak nagyobb a függốségük, hiszen több más faktor hat rájuk, mint a specifikusakra).

A következô lépés a relációmátrix kitöltetése a döntéshozókkal. Kutatásunkban három közlekedési szakértő konszenzusával a következő elérhetôségi mátrixot kaptuk (3. táblázat, külön nem jelezzük a reláció és egységmátrix összeadását, csak az eredményét).

A kitöltók egy workshop keretében, saját szakmai tapasztalatuk és véleményük alapján, konszenzusos kitöltést valósítottak meg, azaz a mátrix egyes rubrikái szakértői egyetértést tükröznek. Természetesen töreked- kitöltési eredményeit. Látható, hogy a specifikusabb tényezók sorában szerepel több 1-es (amely a kapcsolat meglétét és a más elemekre gyakorolt hatást jelenti), míg az általánosabb tényezốk oszlopában van több 1-es (amely jelzi, hogy több elemtól függenek). Már ebben a fázisban fontos pluszinformációkat lehet megállapítani a rendszerról az ISM és a kitöltések segítségével.

A végsố elérhetôségi mátrix konstruálásához a fenti bináris mátrixot a 4-dik hatványra emeltük (lásd [2]), magasabb hatványozás már nem befolyásolta az 1-esek számát, ezáltal a tranzitivitás kritériuma teljesült. A Boole-algebra már említett összeadási és szorzási szabályait követtük a kalkulációban. Az eredményeket a 4. táblázat demonstrálja.

4. táblázat

A rendszerelemek végsố elérhetốségi mátrixa

\begin{tabular}{|c|c|c|c|c|c|c|c|c|c|c|c|c|c|c|c|c|c|c|c|c|c|c|c|}
\hline & r1 & $\mathrm{r} 2$ & r3 & r4 & r5 & r6 & r7 & r8 & r9 & r10 & r11 & r12 & r13 & r14 & r15 & r16 & r17 & r18 & r19 & $\mathrm{r} 20$ & $\mathrm{r} 21$ & $\mathrm{r} 22$ & $\mathrm{r} 23$ \\
\hline r1 & 1 & & & & & & & & & & & & & & & & & & & & & & \\
\hline $\mathrm{r} 2$ & & 1 & & & & & & & & & & & & & & & & & & & & & \\
\hline r3 & . & & 1 & & & & & & & & & & & & & & & & & & & & \\
\hline $\mathrm{r} 4$ & 1 & & & 1 & & & & & & & & & & & & & & & & & & & \\
\hline r5 & 1 & & 1 & & 1 & & 1 & 1 & & & & & 1 & & & & & & 1 & & & & 1 \\
\hline r6 & 1 & & & & & 1 & 1 & & & & & & & & & & & & & & & & \\
\hline r7 & 1 & & & & & & 1 & & & & & & & & & & & & & & & & \\
\hline r8 & 1 & & 1 & & 1 & & 1 & 1 & & & & & 1 & & & & & & 1 & & & & 1 \\
\hline r9 & & 1 & & & & & & & 1 & & & & & & & & & & & & & & \\
\hline r10 & & 1 & & & & & & & & 1 & & & & & & & & & & & & & \\
\hline r11 & . & 1 & & & & & & & & & 1 & & & & & & & & & & & & \\
\hline r12 & 1 & & 1 & & & & 1 & & & & & 1 & & & & & & & & & & & 1 \\
\hline r13 & 1 & & 1 & & & & 1 & & & & & & 1 & & & & & & & & & & 1 \\
\hline r14 & 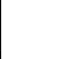 & 1 & 1 & & & & & & & 1 & & & & 1 & & & & & & & & & \\
\hline r15 & 1 & & & 1 & & & 1 & & & & & & & & 1 & & & & & & & & \\
\hline r16 & 1 & & & 1 & & & & & & & & & & & & 1 & & & & & & & \\
\hline r17 & 1 & & & 1 & & & & & & & & & & & & & 1 & & & & & & \\
\hline r18 & 1 & & 1 & & 1 & & 1 & 1 & & & & & 1 & & & & & 1 & 1 & & & & 1 \\
\hline r19 & 1 & & 1 & & 1 & & 1 & 1 & & & & & 1 & & & & & & 1 & & & & 1 \\
\hline $\mathrm{r} 20$ & 1 & 1 & & & & 1 & 1 & & 1 & & & & & & & & & & & 1 & & & 1 \\
\hline r21 & 1 & & 1 & & & 1 & 1 & & & & & & 1 & & & & & & & & 1 & & 1 \\
\hline $\mathrm{r} 22$ & 1 & 1 & & & & & 1 & & 1 & 1 & 1 & & & & & & & & & & & 1 & \\
\hline $\mathrm{r} 23$ & 1 & & & & & & 1 & & & & & & & & & & & & & & & & 1 \\
\hline r24 & 1 & & & & & & 1 & & & & & & & & & & & & & & & & \\
\hline Dep. & 18 & 7 & 9 & 4 & 4 & 3 & 14 & 4 & 3 & 3 & 2 & 1 & 6 & 1 & 1 & 1 & 1 & 1 & 4 & 1 & 1 & 1 & 9 \\
\hline
\end{tabular}

Forrás: saját szerkesztés

hettünk volna nagyobb reprezentativitásra, de az első fejezetben említett szakirodalmi példáknál is elegendônek fogadták el három (sốt esetenként egy) szakértő
A 4. táblázat egyrészt tehát a végső elérhetőségi mátrix, másrészt mutatja az ISM-eljárás következó lépését (3), (4), azaz a befolyásoló erô és a függóség ki- 


\section{Az ISM iterációs fázisa}

\begin{tabular}{|c|c|c|c|c|}
\hline & Reachability set & Antecedent set & Intersection set & Level \\
\hline $\mathrm{r} 1$ & 1 & $1,4,5,6,7,8,12,13,15,16,17,18,19,20,21,22,23,24$ & 1 & I. \\
\hline $\mathrm{r} 2$ & 2 & $2,9,10,11,14,20,22$ & 2 & I. \\
\hline r3 & 3 & $3,5,8,12,13,14,18,19,21$ & 3 & I. \\
\hline r4 & 1,4 & $4,15,16,17$ & 4 & \\
\hline r5 & $1,3,5,7,8,13,19,23$ & $5,8,18,19$ & $5,8,19$ & \\
\hline r6 & $1,6,7$ & $6,20,21$ & 6 & \\
\hline $\mathrm{r} 7$ & 1,7 & $5,6,7,8,12,13,15,18,19,20,21,22,23,24$ & 7 & \\
\hline r8 & $1,3,5,7,8,13,19,23$ & $5,8,18,19$ & $5,8,19$ & \\
\hline r9 & 2,9 & $9,20,22$ & 9 & \\
\hline r10 & 2,10 & $10,14,22$ & 10 & \\
\hline r11 & 2,11 & 11,22 & 11 & \\
\hline r12 & $1,3,7,12,23$ & 12 & 12 & \\
\hline r13 & $1,3,7,13,23$ & $5,8,13,18,19,21$ & 13 & \\
\hline r14 & $2,3,10,14$ & 14 & 14 & \\
\hline r15 & $1,4,7,15,24$ & 15 & 15 & \\
\hline r16 & $1,4,16$ & 16 & 16 & \\
\hline r17 & $1,4,17$ & 17 & 17 & \\
\hline r18 & $1,3,5,7,8,13,18,19,23$ & 18 & 18 & \\
\hline r19 & $1,3,5,7,8,13,19,23$ & $5,8,18,19$ & $5,8,19$ & \\
\hline $\mathrm{r} 20$ & $1,2,6,7,9,20,23$ & 20 & 20 & \\
\hline $\mathrm{r} 21$ & $1,3,6,7,13,21,23$ & 21 & 21 & \\
\hline $\mathrm{r} 22$ & $1,2,7,9,10,11,22$ & 22 & 22 & \\
\hline r23 & $1,7,23$ & $5,8,12,13,18,19,20,21,23$ & 23 & \\
\hline $\mathrm{r} 24$ & $1,7,24$ & 15,24 & 24 & \\
\hline
\end{tabular}

\begin{tabular}{|c|c|c|c|c|}
\hline & Reachability set & Antecedent set & Intersection set & Level \\
\hline $\mathrm{r} 4$ & 4 & $4,15,16,17$ & 4 & II. \\
\hline r5 & $5,7,8,13,19,23$ & $5,8,18,19$ & $5,8,19$ & \\
\hline r6 & 6,7 & $6,20,21$ & 6 & \\
\hline r7 & 7 & $5,6,7,8,12,13,15,18,19,20,21,22,23,24$ & 7 & II. \\
\hline r8 & $5,7,8,13,19,23$ & $5,8,18,19$ & $5,8,19$ & \\
\hline r9 & 9 & $9,20,22$ & 9 & II. \\
\hline $\mathrm{r} 10$ & 10 & $10,14,22$ & 10 & II. \\
\hline r11 & 11 & 11,22 & 11 & II. \\
\hline r12 & $7,12,23$ & 12 & 12 & \\
\hline r13 & $7,13,23$ & $5,8,13,18,19,21$ & 13 & \\
\hline r14 & 10,14 & 14 & 14 & \\
\hline r15 & $4,7,15,24$ & 15 & 15 & \\
\hline $\mathrm{r} 16$ & 4,16 & 16 & 16 & \\
\hline r17 & 4,17 & 17 & 17 & \\
\hline $\mathrm{r} 18$ & $5,7,8,13,18,19,23$ & 18 & 18 & \\
\hline r19 & $5,7,8,13,19,23$ & $5,8,18,19$ & $5,8,19$ & \\
\hline $\mathrm{r} 20$ & $6,7,9,20,23$ & 20 & 20 & \\
\hline
\end{tabular}




\begin{tabular}{l|c|c|c|}
$\mathrm{r} 21$ & $6,7,13,21,23$ & 21 & 21 \\
$\mathrm{r} 22$ & $7,9,10,11,22$ & 22 & 22 \\
$\mathrm{r} 23$ & 7,23 & $5,8,12,13,18,19,20,21,23$ & 23 \\
$\mathrm{r} 24$ & 7,24 & 15,24 & 24
\end{tabular}

\begin{tabular}{|c|c|c|c|c|}
\hline & Reachability set & Antecedent set & Intersection set & Level \\
\hline r5 & $5,8,13,19,23$ & $5,8,18,19$ & $5,8,19$ & \\
\hline r6 & 6 & $6,20,21$ & 6 & III. \\
\hline r8 & $5,8,13,19,23$ & $5,8,18,19$ & $5,8,19$ & \\
\hline $\mathrm{r} 12$ & 12,23 & 12 & 12 & \\
\hline r13 & 13,23 & $5,8,13,18,19,21$ & 13 & \\
\hline r14 & 14 & 14 & 14 & III. \\
\hline r15 & 15,24 & 15 & 15 & \\
\hline r16 & 16 & 16 & 16 & III. \\
\hline r17 & 17 & 17 & 17 & III. \\
\hline r18 & $5,8,13,18,19,23$ & 18 & 18 & \\
\hline r19 & $5,8,13,19,23$ & $5,8,18,19$ & $5,8,19$ & \\
\hline $\mathrm{r} 20$ & $6,20,23$ & 20 & 20 & \\
\hline $\mathrm{r} 21$ & $6,13,21,23$ & 21 & 21 & \\
\hline r22 & 22 & 22 & 22 & III. \\
\hline $\mathrm{r} 23$ & 23 & $5,8,12,13,18,19,20,21,23$ & 23 & III. \\
\hline $\mathrm{r} 24$ & 24 & 15,24 & 24 & III. \\
\hline
\end{tabular}

\begin{tabular}{c|c|c|c|c} 
& Reachability set & Antecedent set & Intersection set & Level \\
\hline r5 & $5,8,13,19$ & $5,8,18,19$ & $5,8,19$ & $5,8,19$ \\
r8 & $5,8,13,19$ & $5,8,18,19$ & 12 & IV. \\
r12 & 12 & 12 & 13 & IV. \\
r13 & 13 & $5,8,13,18,19,21$ & 15 & IV. \\
r15 & 15 & 15 & $5,8,19$ & 20 \\
r18 & $5,8,13,18,19$ & 18 & 21 & IV. \\
r19 & $5,8,13,19$ & $5,8,18,19$ & 21 &
\end{tabular}

\begin{tabular}{c|c|c|c|c} 
& Reachability set & Antecedent set & Intersection set & Level \\
\hline r5 & $5,8,19$ & $5,8,19$ & $5,8,19$ & V. \\
r8 & $5,8,19$ & $5,8,19$ & $5,8,19$ & V. \\
r18 & $5,8,18,19$ & 18 & 18 & $5,8,19$ \\
r19 & $5,8,19$ & $5,8,19$ & 21 & V. \\
r21 & 21 & 21 & Intersection set & \\
\multicolumn{2}{r|}{} & Reachability set & Antecedent set & 18
\end{tabular}

Forrás: saját szerkesztés 
számítását a rendszer minden egyes elemére. Minél nagyobb egy tényező befolyásoló ereje, annál több másik tényezôre gyakorol hatást (a hatás erôsségét nem méri az ISM, ahogy már említettük), minél nagyobb egy tényezố függốsége, annál több másik rendszerösszetevô gyakorol rá hatást. Az r18-as elem, azaz az átszállás szükségessége, rendelkezik a legnagyobb befolyásoló erôvel, 9-cel; míg a szolgáltatási minôség tényezô, vagyis az r1, a leginkább függő 18 -as értékkel. Ezek az értékek természetesen már tartalmazzák a tranzitivitás miatti közvetett kapcsolatokat, így jobban jellemzik a rendszert, mint a 3. táblázat.

A végsố elérhetôségi mátrix alapján megrajzolható a rendszer elemeinek direkt gráfja, amelyben a közvetlen elemkapcsolódásokat szerepeltethetjük. Ezt demonstrálja az 1. ábra. hatásait akarják a döntéshozók végigkövetni, elegendő az 1. ábra nyilait követni, és így prognosztizálható a fejlesztés jövőbeli, externális hatása (az externálist itt a rendszeren belüli, de az elemen kívüli hatásként értelmezhetjük). A közvetlen externális hatást a nyilak jelenléte jelzi, a közvetett hatásokat pedig az adott elemból kiinduló nyilak utolsó elemig történô végigkövetése teszi lehetôvé. Stratégiai döntéshozatal esetében ez fontos támogató eszköz lehet a döntéshozók számára.

Annak érdekében, hogy még szofisztikáltabb eredményekhez jussunk, érdemes elvégezni az ISM következô lépését, amelyet iterációs fázisnak is neveznek, és az előző fejezet (5)-ös képlete ír le. Ez az iterációs fázis a rendszer elemeinek befolyásolási ereje szerint alkot hierarchiaszinteket, a legmagasabb szinten a legnagyobb hatású tényező lett meghatározva, a legal-

1. ábra

A közlekedési elemek direkt kapcsolódásai

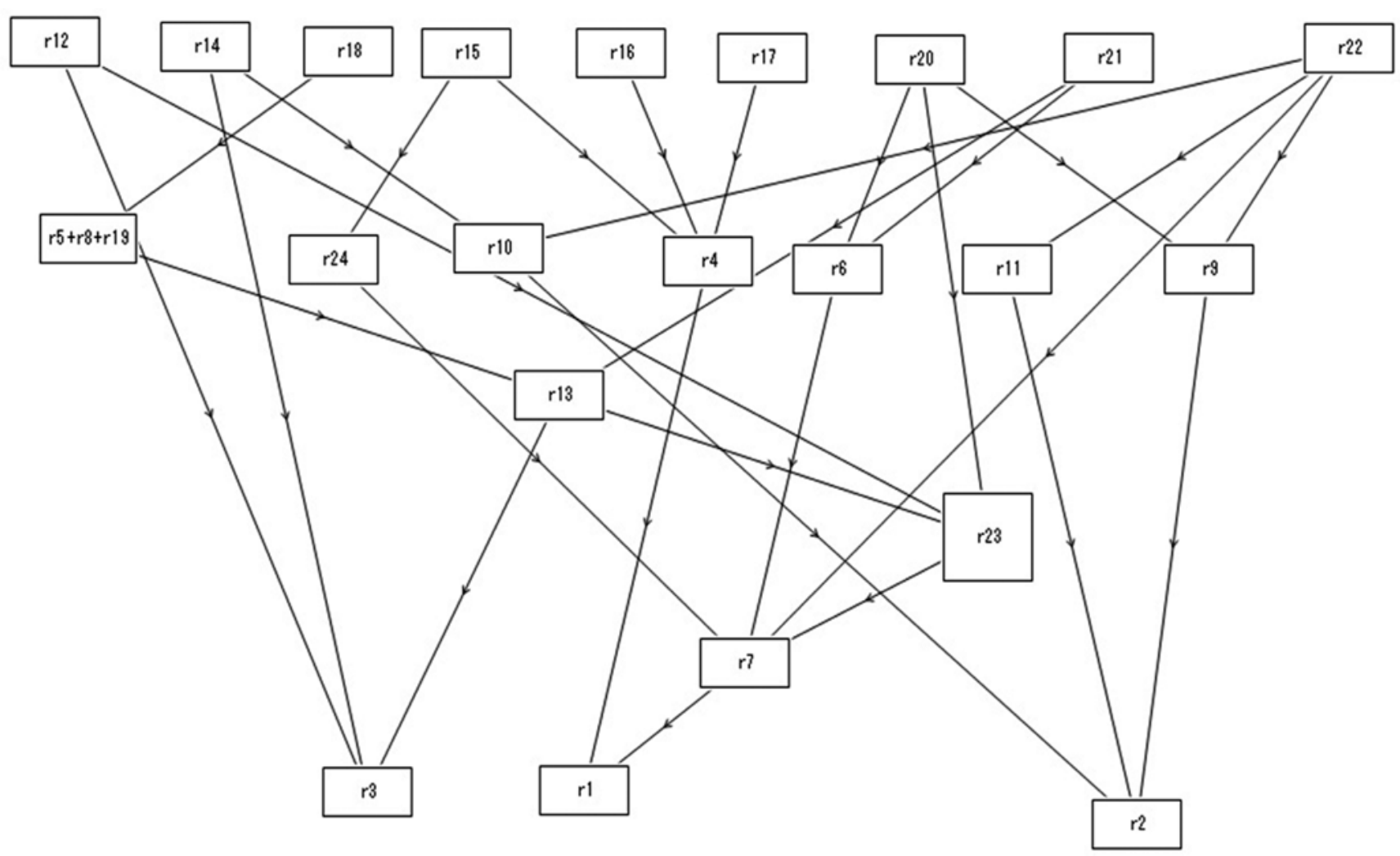

Nagyon fontos, új következtetések vonhatók le az 1. ábrából. 3 tényező r5, r8 és r19 integráltan szerepelnek, vagyis ugyanazon elemeket befolyásolnak, és ugyanazoktól függenek. Vannak olyan elemek (r12, $\mathrm{r} 14, \mathrm{r} 18, \mathrm{r} 20, \mathrm{r} 21, \mathrm{r} 22)$, amelyek két általános elemet is befolyásolnak (általános az r1, r2, r3), így fejlesztésük nagyobb hatással lehet az egész rendszerrel szembeni felhasználói elégedettségre, mint más tényezők fejlesztése. Amennyiben egy bizonyos elem fejlesztésének só szinten pedig a leginkább függó tényezók vannak. Ahogy a 2. ábrán látható is, az r18-as elemre nem hat már tényező a rendszeren belül, de a legtöbb hatást gyakorolja más elemekre. Ezzel ellentétesek az r1, r2 és r3 faktorok, amelyek csak függenek a többiektól, de hatást nem gyakorolnak másokra. Már említettük, hogy általánosságuk miatt ez nem meglepó, de a hierarchiaszinteken való faktorpozíciók értékes új információkkal láthatják el a döntéshozókat. 


\section{Az elemek befolyásolási hierarchiája}

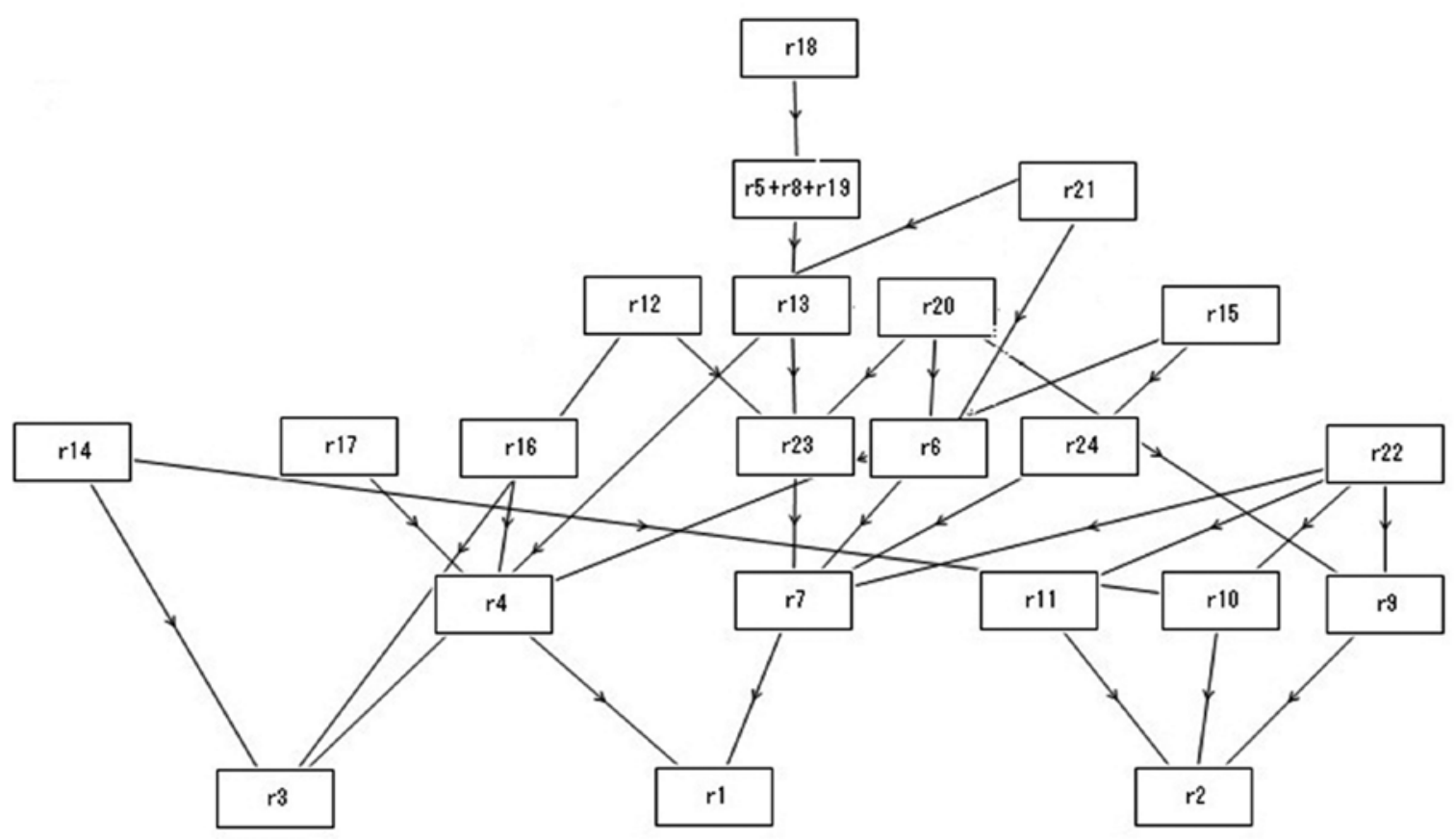

\section{Összegzés}

Egy döntési probléma rendszerelemeinek kapcsolódási hálója fontos információkat tartalmaz a döntéshozók számára. A tanulmányban bemutatott közlekedési rendszerre vonatkozó kutatásban az egyes tényezók egymásra hatása a végsố fejlesztési döntést is jelentôsen befolyásolhatja, hiszen a fejlesztési forrásokat úgy célszerú elosztani, hogy a többi elemre nagy befolyásoló erővel bíró tényezốket jobban megéri fejleszteni, mint a kevesebb hatású elemeket. Az ISM önmagában is jelentôsen segítheti a stratégiai döntéshozatalt azzal, hogy egy szisztematikus hálót közöl a döntési problémáról a döntéshozókkal. Hatásos azonban más módszerekkel kombinálva is, jó kiegészítôje az AHP-nek vagy a gráfelméletnek.

Ki kell emelni azonban a módszer legfóbb hiányosságát; nem közöl információt az elemkapcsolatok erôsségéról. A mátrixok binaritásának elônye a matematikai könnyen kezelhetôség, hátránya viszont, hogy csak a kapcsolat létét vagy nemlétét tudja kifejezni, az erôsséget nem lehet betenni a modellbe. Ennek kezelése a jövőre vonatkozó kutatási irány, túlmutat e tanulmány keretein.

Szándékunk az volt a tanulmány megírásával, hogy az ISM-et, mint hatékony menedzsmentdöntéseket segítő módszert, megismertessük a szélesebb tudományos és szakmai közvéleménnyel.

\section{Lábjegyzet}

${ }^{1}$ Köszönetnyilvánítás: Ez a tanulmány a TÁMOP-4.2.2.A-11/1/ KONV-2012-0051 projekt keretei között készült el.

\section{Felhasznált irodalom}

Duleba, Sz. - Mishina, T. - Shimazaki, Y. (2012): A dynamic analysis on public bus transport's supply quality by using AHP. Transport, 27(3): p. 268-275.

Eswarlal, V.K. - Dey, P.K. - Shankar, R. (2011): Enhanced renewable energy adoption for sustainable development in India: Interpretive Structural Modeling Approach. World Renewable Energy Congress, Linkoping 2011. 05. 8. 13. Conference Proceedings: p. 351-358.

Faisal, M.N. - Banwat, D.K. - Shankar, R. (2006): Supply Chain Risks Mitigation: modelling the enablers. Business Process Management Journal, 12(4): p. 532-552.

Gorvett, R. - Liu, N. (2007): Using interpretive structural modeling to identify and quantify interactive risks. Astin Colloquium Call for papers: p. 2-11.

Huang, J.-J. - Tzeng, G.-H. - Ong, C.-S. (2005): Multidimensional data in multidimensional scaling using the analytic network process. Pattern Recognition Letters, 26: p. 755-767.

Malone, D.-W. (1975): An introduction to the application of interpretive structural modeling. IEEE,.63(3): p. 397-404.

Mandal, A. - Deshmukh, S.-G. (1994): Vendor selection using interpretive structural modeling (ISM). International Journal of Operations and Production Management, 14(6): p. 52-59. 
Pfohl, H.-C. - Gallus, P. - Thomas, D. (2011): Interpretive structural modeling for supply chain risks. International Journal of Physical Distribution and Management, 41(9): p. 839-859.

Pramod, V.-R. - Banwet, D.-K. (2010): Interpretive Structural Modeling for understanding the inhibitors of a telecom service supply chain. Proceedings of the 2010 International Conference on Industrial Engineering and Operations Management, Bangladesh, 2010. 01. 9. 10.

Qureshi, M.N. - Kumar, D. - Kumar, P. (2007): Modeling the logistics outsourcing relationships variables to enhance shippers productivity and competitiveness in logistics supply chain. International Journal of Production and Performance Management, 56(8): p. 689-714.

Ravi, V. - Shankar, R. - Tiwari, M.K. (2005): Productivity improvement of a computer hardware supply chain. International Journal of Production Performance Measurement, 54(4): p. 239-255.
Tabrizi, R.S. - Foong, Y.P. - Ebrahimi, N. (2010): Using Interpretive Structural Modeling to determine the relationship among knowledge management criteria inside Malayzian organizations. World Academy of Science, Engineering and Technology, 72/2010

Thakkar, J. - Kanda, A. - Deshmukh, S.-G. (2008): Evaluation of buyer-supplier relationships using an integrated mathematical approach of interpretive structural modeling (ISM) and graph theoretic matrix: the case study of Indian automotive SME-s. Journal of Manufacturing Technology Management, 19(1): p. 92-124.

Warfield, J.-W. (1974): Developing interconnected matrices in strutural modelling. IEEE Transcript on Systems, Men and Cybernetics, 4(1): p. 81-87.

A cikk beérkezett: 2012. 9. hó

Lektori vélemény alapján véglegesítve: 2013. 1. hó

\section{E S Z Á M U N K S Z E R Z Ö I}

Dr. Malota Erzsébet, egyetemi docens, Budapesti Corvinus Egyetem; Gyulavári Tamás, egyetemi adjunktus, Budapesti Corvinus Egyetem; Dr. Kovács Zoltán, egyetemi tanár, Pannon Egyetem; Rendesi István, múszakvezetô, Audi Hungaria Motor Kft.; Dr. Sterbenz Tamás, egyetemi docens, Semmelweis Egyetem Testnevelési és Társadalomtudományi Kar; Gulyás Erika, egyetemi tanársegéd, Semmelweis Egyetem Testnevelési és Társadalomtudományi Kar; Dr. Duleba Szabolcs, fóiskolai docens, Nyíregyházi Főiskola; Dr. Futó Péter, PhD egyetemi magántanár, Budapesti Corvinus Egyetem; Dr. Bokor Zoltán, egyetemi docens, Budapesti Múszaki és Gazdaságtudományi Egyetem; Dr. Udvari Beáta, PhD egyetemi adjunktus, Szegedi Tudományegyetem 